\title{
Bridging Technical Skills Gaps between High School Students and Local Employers
}

\author{
Edward C. Fletcher, Jr., Will Tyson \\ University of South Florida
}

\begin{abstract}
The purpose of this study was to explore how technical skills taught and learned in Florida engineering and engineering technology-themed career academies fit technical skills desired by local employers in technology and manufacturing. The analysis utilized the narratives of 70 students and four teachers from career academies at four high schools and 27 industry leaders from the same geographical region of Florida. Data interpretation led to understanding that employers expressed an urgent need for technical skills using appropriate equipment and technologies, teachers were teaching students technical skills by simulating the real-world work environment, and students valued their abilities to transform their classroom project ideas into tangible products.
\end{abstract}

Keywords: career academy, career and technical education, skills gap, technical skills

\section{Introduction}

Since the Smith Hughes Act of 1917, there has been federal interest and support of career and technical education (CTE) programs historically aimed at preparing students for work (Fletcher, 2006). On the federal level, the Carl D. Perkins Career and Technical Education Act (Perkins IV) is the major federal legislative initiative that supports CTE programs across the nation. It was originally authorized in 1984 and is currently in the process of being reauthorized by Congress. Its purpose is to provide students with college and career readiness skills needed to pursue further education and for successful employment in high demand and high wage careers (Fletcher, 2006).

Traditionally, high schools have emphasized equipping students with skills needed to pursue postsecondary studies (Cohen \& Besharov, 2002); however, there has been an increasing national awareness of the need to better prepare high school students for careers in order to remain internationally competitive (Fletcher, 2006; Fletcher \& Zirkle, 2009; Symonds, Schwartz, \& Ferguson, 2011). On a state level, Florida is one of the trailblazers in terms of its focus on middle and high school CTE programs to assist in workforce development, specifically in pursuit of a strategic plan to align high schools, colleges and universities, and workforce opportunities for its residents. A pivotal legislative initiative is the Florida Career and Professional Education (CAPE) Act enacted in 2007, which required all school districts in the state to establish at least one career academy by the 2008-2009 academic school year (Dixon, Cotner, Wilson, \& Borman, 2011). The primary objective of the legislation was to develop a statewide partnership between industry and educational institutions for economic development particularly in high demand and high wage careers. To that end, all career themed courses within CAPE academies are required to yield an industry certification or college credit for students within that particular career cluster. The career academy model functions on three primary tenets: a smaller learning community; an integrative college preparatory coursework within a career theme; and partnerships between schools and business and industry to increase students' exposure to work through career development and work-based learning opportunities (Kemple \& Snipes, 2000).

Despite prior research examining the effectiveness of career academies (Kemple \& Willner, 2008; Stern, Dayton, \& Raby, 2010), research has not attempted to address how career academies meet the needs of potential employers related to technical skills. Thus, the purpose of this study was to explore how technical skills taught and learned in Florida engineering and engineering technology-themed CAPE academies fit technical skills desired by local employers in technology and manufacturing. Our analysis utilized the narratives of 70 students and four teachers from four high schools and 27 industry leaders from the same geographical region of Florida. The research questions undergirding this study were as follows:

1. What pedagogical practices do teachers use to increase the technical skills of students in 
engineering and engineering technology courses and programs?

2. What are the experiences of students in engineering and engineering technology courses and programs as it relates to technical skills learned?

3. How do employers describe the technical skills needed in technology and manufacturing jobs?

\section{Literature Review}

The term "skills gap" has developed over the last decade in response to mounting concerns that today's youth lack the twenty-first-century knowledge, skills, and dispositions as well as work ethic needed for many middle wage careers. As noted by the Partnership for 21st Century Skills (2010), “College and career readiness is the new direction for $\mathrm{K}-12$ education. Preparing students to transition without remediation to postsecondary education or to careers that pay a living wage, or both, is the ultimate aim of federal and state education policies, initiatives and funding" (p. 6). Surveys of employers repeat a common refrain that potential workers, including young adults, lack the full range of skills to be competitive for jobs that often remain unfilled (Carnevale, Smith, \& Melton, 2011; Carnevale, Smith, \& Strohl, 2010). Symonds et al. (2011) argue that "The growing complaints of a skills gap from some of the nation's most prominent companies and business organizations underscore a hard reality: their growing reluctance to hire young people with just a high school degree" (p. 4).

Criticisms mount against a focus on college preparation solely in K-12 education. Symonds et al. (2011) concluded, "a focus on college readiness alone does not equip young people with all of the skills and abilities they will need in the workplace, or to successfully complete the transition from adolescence to adulthood” (p. 6). The pressure to prepare high school students for both college and careers is particularly true within science, technology, engineering, and mathematics (STEM) fields. The focus on STEM college and career readiness concomitantly promotes an expansion of the national pipeline for STEM career participants (Hernández-Gantes \& Fletcher, 2013). The need to expand the STEM workforce was developed by employers reporting an absence of talent in these areas as well as the promise of growing the nation's profile in economic development and innovation. A more recent focus has been on preparing students for technician jobs that typically do not require a baccalaureate degree or equivalent (Carnevale et al., 2011; Carnevale et al., 2010).

According to Stone (2013), colleges and employers desire that young people demonstrate college and career readiness along three domains of knowledge, skills, and dispositions: academic, occupational, and technical. Academic skills include academic proficiency in math, science, and related areas. Occupational skills (i.e., "soft skills”) relate to ability, willingness to learn and perform, and attitudinal characteristics. Employers are increasingly placing emphasis on potential employees who have the occupational skills needed to perform on the job. Technical skills are the specific competencies employers desire and include industry-recognized, career-specific knowledge bases. Additionally, technological skills are a critical component to carry out technical tasks. The perceived lack of the aforementioned skills in the workforce is the root of the "talent gap" between the skills desired by employers and skills possessed by the workforce.

With the goals of college and career readiness, CTE programs are vehicles for expanding the pipeline of high school students enrolling in postsecondary STEM-related majors and should be pathways into the technician workforce. Hernández-Gantes and Fletcher (2013), for example, advocate for a more coherent workforce development system in the U.S. to connect high schools, community colleges, and four-year universities with established articulation agreements to further align educational institutions to the needs of the workforce. Such a system would give more high school graduates the flexibility to choose STEM college and/or career pathways after high school.

High School Career Academies. Several quantitative studies have examined the effectiveness of career academies concerning student performance metrics (Kemple, 1997; Kemple \& Snipes, 2000; Kemple \& Willner, 2008; Stern et al., 2010). MDRC (formerly Manpower Demonstration Research Corporation) has studied the career academy model since 1993. They employed an experimental research study design involving an economically, racially, and ethnically diverse set of high schools across the country. Their research focused on the effectiveness of the school reform model in relation to student performance in high school as well as transitions into further education and the labor market. MDRC research findings suggested career academy students had more positive social and personal experiences, compared to non-academy students. Career academy students reported increased interpersonal relationships among their teachers and peers and higher levels of school engagement. In addition, career academy students reported increased levels of intrinsic motivation and stronger perceptions of relevance and meaningfulness of course content (Kemple, 1997).

Kemple and Snipes (2000) found the benefits of career academies were higher for students considered atrisk for dropping out of high school. Career academies had a robust and positive impact on those likely to drop out. At-risk academy students had higher attendance rates and credits earned toward graduation and were more likely to graduate on time than at-risk students not enrolled in career academies.

Later, MDRC research by Kemple and Willner (2008) found labor market benefits of career academies 
increased for at-risk male students who graduated from high school. These students had higher average monthly earnings four years after graduation compared to students who did not enroll in career academies. In general, participation in career academies has resulted in increased student engagement, attendance, graduation rates, academic achievement, and long-term employment earnings (Bradby, Malloy, Hanna, \& Dayton, 2007; Kemple \& Snipes, 2000; Kemple \& Willner, 2008; Maxwell \& Rubin, 2000; Silverberg, Warner, Fong, \& Goodwin, 2004; Stern et al., 2010). However, findings have also demonstrated that career academy seniors did not score higher than non-academy students on standardized assessments in mathematics and language arts. According to Stern et al. (2010), “MRDC's null finding about test scores raises questions about what kind of instructional improvement, if any, occurs in career academies” (p. 19). Further, available research has relied on the evaluation of career academies in general and has typically focused on program outcomes.

Fletcher and Cox's (2012) study was one of the few investigations that used qualitative interviewing methods to examine African American students (i.e., 7 males and 8 females) in regards to their decisions to enroll (or not) in career academies. The researchers discovered both African American males and females chose to enroll in a career academy because they believed it provided them with the needed preparation for postsecondary education and added value to their overall high school experiences. Participants also shared that their academy offered a community atmosphere to learn, provided hands-on training to prepare for postsecondary education in their respective fields, and assisted with exploring unique career and postsecondary interests. Additionally, numerous students indicated they did not enroll in academies because they had less time to engage in needed college preparatory coursework and other school activities, such as athletics. Despite numerous career academy studies, research has not explored student experiences, pedagogical practices of teachers, and skills gaps reported by employers grounded in specific career fields such as engineering and engineering technology.

\section{Theoretical Framework}

The career academy model builds upon the premise of contextual teaching and learning to make student learning more meaningful by facilitating connections to real-life occupational situations that increase the relevance of content (Brown, Collins, Duguid, 1989; Hernández -Gantes \& Brendefur, 2003). Within career academies, the occupational context serves as the source of relevant learning tasks and concept applications involving authentic representations of what people do in the world of work (Hernández-Gantes \& Brendefur, 2003; Newmann, King, \& Carmichael, 2007). The authenticity of the learning situations ("authentic pedagogy") is at the core of teaching and learning in career academies (Castellano, Sundell, K., Overman, \& Aliaga, 2012; Newmann, Secada, \& Wehlage, 1996). As students progressively acculturate to the knowledge, skills, and attitudes expected in an occupational context, contextual learning becomes richer for students. Thus, it is reasonable to expect that, based on the quality of such learning experiences, students will have enhanced skills around a related career context (e.g., engineering).

In schools, it has been extensively documented that students often find teaching and learning to be devoid of meaning and are prone to question the relevance of instructional tasks (Castellano et al., 2012; HernándezGantes \& Brendefur, 2003). To address this disconnect in teaching and learning, career academies emphasize learning in specific occupational contexts to enhance the relevance of student experiences. The premise is that the authenticity of occupational contexts (e.g., engineering) provides for opportunities to make learning more meaningful for students (Newmann \& Wehlage, 1995; Stipanovic, Lewis, \& Stringfield, 2012). Further, the premises of contextual teaching and learning are supported by research conducted over the past two decades (Newmann et al., 2007). Results from a number of studies suggest that students participating in programs emphasizing contextual and authentic teaching and learning show enhanced student engagement and higher achievement (Newmann et al., 2007; Newmann \& Whelage, 1996).

Most research on career academies has not evaluated the nature and impact of teaching and learning tasks on students' experiences or how career academies address the needs of employers. Instead, the predominant focus has been on student outcomes (Kemple \& Willner, 2008; Stern et al., 2010). In this regard, lingering questions exist, including how teaching and learning in engineering and engineering technology career academies promote the technical skills needed of potential employees. What is the nature of teaching and learning tasks emphasized in engineering and engineering technology career academies? In this study, we explored how teaching and learning occurs in engineering and engineering technology courses and programs, and what technical skills are desired by employers.

\section{Need for the Study}

Research on STEM pathways generally focused on matriculation into STEM degree programs at four-year universities with a growing focus on two-year colleges because of federal policies. However, little is known about the role of federal policies, such as the Carl D. Perkins Career and Technical Education Act (Perkins IV) and state policies such as Florida's 2007 CAPE Act, in preparing high school students to enter STEM careers (Wang, 2013). In fact, currently, more than 500,000 Florida students enroll in secondary and postsecondary CTE programs. Among Florida secondary schools, 67 school districts offer CTE courses and career academies 
(Florida Department of Education, 2016). Further, in Florida, there are currently 96 high schools with 156 academies affecting 26,070 students that are members of the National Academy Foundation, an acclaimed national network of high school career academies that focus on rigorous, career-themed curricula developed with business, industry, and educational expertise (National Academy Foundation, 2014). Florida has the largest number of students enrolled in NAF academies compared to any other state within the United States. The Florida context, with respect to industry and secondary education, provides an excellent opportunity to show how technical skills are taught and learned in relation to skills identified as areas of need by employers.

Florida high schools employ STEM career academies as a strategy to provide strong pathways into emerging technology education programs. Career academies in Florida are defined as "research-based programs that integrate a rigorous academic curriculum with an industry-driven career curriculum" (Florida Department of Education, 2006, para. 1). Florida's STEM-themed career academies offer training in information technology, health sciences, and science, technology, engineering, and mathematics. Career academies typically operate as schools-within-schools and provide an equal emphasis on academic and vocational curricular content. This serves the needs of students with a broad range of ability levels (Kemple \& Snipes, 2000). Career academies attempt to facilitate career pathways, defined as a series of educational steps and professional experiences with the end result of employment in a desired industry or occupational sector (Jenkins, 2006). As a result of the implementation of the Florida CAPE Act, there are currently 2,058 CAPE academies registered at 415 high schools and 206 middle schools (Florida Department of Education, 2016).

According to the latest figures from the National Association of Manufacturers (2016), 336,200 Floridians work in manufacturing at 12,162 firms, earning an average annual compensation of $\$ 41,839$ in nonfarm businesses. This is well above the median per capita income of \$26,582. Manufacturers accounted for 4.95\% of the total gross state product in Florida and employed $4.17 \%$ of the nonfarm workforce. The top three Florida manufacturing sectors were computer and electronic products, chemical products, and food, beverage, and tobacco products. Companies represented in this study manufactured a variety of products, but focused primarily on parts for larger products used in fields such as defense/avionics and medicine.

As states such as Florida continue to invest in and implement high school reform initiatives aimed at improving college and career readiness, it is increasingly critical that we determine how students benefit from participation in career academies, in terms of preparation for the workforce and higher education. Given the impact of CTE programs in the overall educational enterprise as well as investments from federal funding bodies, policymakers and other educational constituents expect these programs to provide a return on investment for students who participate (Israel, Myers, Lamm, \& Galindo-Gonzalez, 2012). The abundance of literature related to the effectiveness of career academies and CTE education are quantitative in nature with a focus on comparing students' achievement and labor market outcomes as a result of participation (Kemple, 1997; Kemple \& Snipes, 2000). By contrast, few studies have utilized qualitative methods to understand the experiences of students and teachers within career academies (Fletcher \& Cox, 2012). Interviews with students, teachers, and employers allowed us to learn about the interplay between skills desired by local STEM employers and the skills developed in career academies by the youngest members of the local workforce.

\section{Data, Methods and Analysis}

We used a phenomenographic research approach to study the ways high school students, teachers, and employers described their experiences and made meaning from learning, engaging, and developing knowledge and understanding within the fields of engineering and engineering technology (Akerlind, 2007). Data for this manuscript came from a large study of secondary and higher education pathways into technician careers in a region of Florida made up of five counties and five corresponding school districts. Analyses emerged from face-to-face interviews with three stakeholder groups along these pathways:

1. 70 high school students enrolled in four engineering/engineering technology-themed career academies housed at four high schools within three districts;

2. Four teachers, one from each of the four high school career academies; and

3. 27 employers in technology and manufacturing businesses located in the five county region.

We assured all student, teacher, and employer participants' confidentiality. Therefore, the names of all interviewees and schools were changed.

Schools in this study were a subsample of schools within the five county region that included an engineering or engineering technology-themed career academy. Local community college technician education faculty and district administrators responsible for STEM curricula recommended these schools. We initiated contact with school principals and career academy administrators and teachers in order to gain approval for this study. We compensated schools for their participation by providing stipends to each school.

Procedures. Student participation was voluntary and subject to parental informed consent. Career academy teachers invited the research team to their classrooms to conduct student interviews during class time. We conducted each interview within the classroom, but away from other students and class activities. 
Interviews lasted 20 to 30 minutes. Students received a small gift for their participation. Teacher interviews took place during a planning period or other non-instructional time.

Employers interviewed for this study were primarily industry partners associated with local community college engineering technology programs. We recruited other participants through snowball sampling. We interviewed each employer either at his or her job site or over the phone at the employer's discretion. Field notes included additional information about the employer and their company. To ensure trustworthiness, we used data triangulation by integrating student, teacher, and employer interviews.

Data Analysis. We audiotaped interviews, and then later transcribed and thematically coded them. We transcribed field notes and coded them as well. Each interview lasted 20-30 minutes and included open-ended questions with respect to pathways into technician careers. We asked industry leaders about the skill sets they desired for their workers, recruitment and hiring processes, and their perceptions of the skill sets and fields of knowledge that would be essential for future workers in the local technology and manufacturing workforce. We asked teachers about the organization of their career academy, pedagogical approaches to instruction, student characteristics, and typical postsecondary pathways of their students. We asked students about their interests in engineering and engineering technology, how they learned about their career academy and careers, and factors influencing their enrollment in the program. We also asked students about their career academy coursework, perceived skills developed in the course, and their postsecondary academic and career goals and aspirations.

Interviews were coded using qualitative software (Atlas.ti), allowing researchers to sort transcripts by words and phrases that corresponded to themes related to technical skills desired by industry, taught by teachers, and acquired by students. We used these themes to construct a coding tree for the initial coding of each interview. In order to focus analyses on technical skills desired by employers, taught by teachers, and developed by students, we re-visited the employer-coding tree and focused on the following codes: job descriptions, worker skills desired, company needs, and workforce needs. We then re-coded student and teacher interviews to uncover similar themes. For example, members of the research team re-coded each interview for terms such as "CAD" and "CNC" to identify passages where individuals discussed software or machines. Inter-rater reliability of at least $80 \%$ was established for the initial round of coding.

We used pseudonyms to ensure confidentiality. We used a gender-specific first name for each employer. The first two letters of each teacher's name corresponds to the name of their school (i.e., Mr. Palmer/Packard HS, Mr. Wells/Weston HS, Mr. McGee/McArthur HS, Mr.
Stein/Stearns HS). We identified students by a genderspecific first name and the name of their high school.

McArthur High School, a magnet school, is located in a large suburban setting with a population of 1,746 students. It was comprised of 50\% male and 50\% female, $19 \%$ minority, and $21 \%$ economically disadvantaged students. Packard High School is located in a small urban setting with a population of 1,866 students. It was comprised of $51 \%$ male and $49 \%$ female, $15 \%$ minority, and $17 \%$ economically disadvantaged students. Stearns High School is located in a large suburban setting with a population of 2,009 students. It was comprised of 51\% male and $49 \%$ female, $56 \%$ minority, and $45 \%$ economically disadvantaged students. Weston High School is located in a large urban setting with a population of 1,135 students. It was comprised of $56 \%$ male and $44 \%$ female, $86 \%$ minority, and $75 \%$ economically disadvantaged students. It was a historically black institution and served as a magnet STEM school.

Limitations. Based on confidentiality measures, we did not provide information related to individual teachers' and students' backgrounds and attributes. Therefore, findings from this study are not generalizable. Findings are contextually situated within one place and time with a unique sample of employers, teachers, and students. Nevertheless, we hope this research will initiate future qualitative and quantitative research that can address these limitations.

\section{Data Interpretations}

Industry: The Need for Technical Skills Using Appropriate Equipment and Technologies. We asked employers to describe jobs for which their company regularly hires. Example occupations included welders (Harold), sales people (Alan), test technicians (Harry), shop helpers (Tom), trim carpenters (Ken), and mechanical designers (Paul). The most common occupations mentioned, when describing the lack of skilled workers, were CNC machinists and CNC machine operators. These were the second and fourth jobs with the highest vacancy rates, according to a recent analysis of area manufacturing skills gaps (Manufacturing Skills Gap Report, 2013). CNC machinists and operators required a complicated skillset that "starts out with good STEM education" (Jim). CNC machines have a computer control panel and require a special programming language. Thus, machinists need to know relevant programming software as well as how to set up the machine and how to use the tools, according to Jim.

Jim owns a business he described as a "machine shop" that specializes in defense subcontracts building parts for airplanes, weapons, and other machines. He described difficulties with finding CNC machinists. Jim lamented that "nobody knows we exist" when describing jobs in the local manufacturing industry. 
Kevin is one of the younger employers interviewed for the project and the latest in his family to run his small multigenerational family-owned shop. He has about 30 employees, 20 of whom work on CNC machines. Kevin explained that CNC machinists are vital to his company's operation, but the pool of available machinists seems to be drying up: "The largest need we have is for CNC machinists. That...seems to be the dying breed if you will or it's not so much a dying breed, it's just not a growing breed."

Don started his own company after what he described as "too many years" as a representative for companies in the same field. He lamented that local employers were not finding local workers with CNC experience and have to search nationally for people with the right skills:

I see a lot of applications for people. I get asked all the time, "Where can I get an employee?" And the biggest thing that I see that's wrong with the Florida education system is they're...putting out such basic employees that a lot of companies don't want to handle them. [Companies are] still going up north to find actually trained employees and this is primarily in CNC machine tool operators.

According to Don, CNC machining was "totally being neglected" in Florida, particularly among educators. Don placed the onus on high schools and community colleges to collaborate with local companies to acquire the machines necessary to train students for the local workforce. Don claimed there were "literally hundreds of companies" willing to hire out of local educational institutions: "I'm sure those people would get a job like that [snaps], and a good job. You know we're not talking about $\$ 20,000$ a year job, we're talking $\$ 30,000, \$ 40,000, \$ 50,000$ type thing.”

Several narratives from employers discussed potential salaries earned in their companies. For example, when asked how to motivate young people to train for and pursue CNC jobs, Don responded:

If you're a true CNC operator/programmer...you're constantly being challenged with completely new designs, yet you're totally responsible for the entire set up, the machine, and the quality. A person like that generally can run four to six machines by himself and that person generally earns between $\$ 60,000$ to $\$ 90,000$ a year. Uh, motivation?

The most common skills mentioned by employers was familiarity with computer-aided design (CAD) and computer-aided manufacturing (CAM) programs, such as SolidWorks. For example, one interviewee noted:

For basically any career, and beyond that in engineering technology, I see people who are fluent in CAD, in engineering CAD systems and multiple CAD languages. So, that might be SolidWorks; that might be Pro/ENGINEER; that might be AutoCAD; that might be Inventor....” (Paul)

These programs allow workers to visualize their ideas in $3 \mathrm{D}$ and translate them into $2 \mathrm{D}$ drawings. CAD programs also allow workers to communicate with $3 \mathrm{D}$ printers. Workers did not necessarily need to be able to design something from scratch, but at least have "the ability to relate to and download a SolidWorks program to make a sample of a part or whatever" (Wes).

Employers were particularly impressed if students had early CAD/CAM experience. Wes was active in a local initiative to link employers with high schools. His company sponsored a local high school robotics team. Nick mentioned a recent high school tour by students who were taking SolidWorks. Ken advocated teaching SolidWorks to reduce elementary and high school skills gaps.

For many jobs, the employers articulated that CAD skills were a necessity. Tom stated, "I can't get them a job here until they have SolidWorks because SolidWorks is basic blueprints. If you can't read a blueprint, you can’t run a brake; you can’t run a water jet...”. Tom primarily hired community college and four-year university students because he had trouble hiring workers with experience overall. He complained that the local university engineering program did not teach SolidWorks until junior year. Tom recalled that after hiring a disabled veteran he recruited from the local university, "the first thing I did is I made him go over to [local community college], sign up for, take SolidWorks..."

Paul is a degreed engineer and executive at a small industrial design firm that specialized in product design development for small vehicles and medical devices. His company did not hire employees with only a high school education, although he stated that someone with a foundation in physics from high school could develop the necessary technological knowledge on the job. Paul also complained that universities did not teach CAD systems well. He believed people with fluency in CAD programs had an advantage in the job market:

The two industry standards are Pro/ENGINEER and SolidWorks, and if you had those skills coming out of a university program or a college program with even two years of experience, you would have the foundation to work in basically any place that makes something.

Paul then gave an example of how a technician with the proper CAD skills could be effective in his company: We have a machine here that runs almost 24/7. Our machine broke down the other day and we have a technician from the company coming out but they can't be here until Monday. And, that's costing us money.... We run basic maintenance on it, but when we have problems no one here knows how to fix them. That would be awesome. If a student came in here and knew SolidWorks and Pro/ENGINEER, and how to make technical drawings, and...could take apart, you know, 50 percent of the machines on the market and understand how they work, that person would definitely be hired... And, that person doesn't exist. We've never met anyone like that.

Don, Tom, and Paul, as local employers, described the challenge of finding potential employees, particularly those individuals who have the knowledge and 
technological skills, including programming language and software programming, to operate CNC machines. While they seemed to be frustrated with the lack of secondary and postsecondary education preparation for specific job-related (technical) skills, we were surprised at the lack of initiative taken to address the issue. First, standard practices within career academies require substantive partnerships with business and industry for the purpose of informing curricula, connecting skills gaps for students and teachers, and staying abreast of the needs and trends of industry practices in the real-world of work. However, it was apparent to us that Don and Tom's engagement with high schools and colleges/universities were lacking, while Paul seemed more engaged with secondary and postsecondary education programs. Second, Don discussed earnings as a primary motivator for attracting potential employees to CNC positions. However, it is important that local employers express to potential employees the value of having a passion for one's career, as focusing on monetary gains is limiting and a rather short-term perspective. Third, we wondered about the commitment from local employers in terms of training and developing their employees. Based on our discussions with Don, Tom, and Paul, they placed the sole responsibility of preparation with secondary and postsecondary CTE programs. This practice we found to be problematic.

Teachers: Teaching Technical Skills by Simulating the Real-World Work Environment. An emphasis on contextual teaching and learning. High school engineering and engineering technology academy teachers attempted to prepare their students to fill skills gaps in the local workforce. Teachers taught students how to use and apply computer-aided design (CAD) programs and develop other technical skills through a combination of lecture and either guided or self-directed, hands-on activities. Teachers used lectures to supplement laboratory activities. Laboratory activities provided students with hands-on experiences that allowed them to simulate what they would experience in a local industry job by working individually or in pairs or small groups. Mr. Palmer assigned students in pairs to each station. His curriculum required students to complete 20 different lessons in 30 days. Mr. Palmer described:

So one team might be in aerodynamics, while I've got another team working on electricity and electronics... Or, I might have a pair in here working on CAD/CAM or Master CAM or any of those... And, every pair of kids has something to do... It's self-paced as far as, you know, you got the 20 lessons in 30 days.

The teachers also discussed how they provided students with self-directed projects that simulated the real-world work environment. Within that context, Mr. Stein explained how he structured his lessons with students:

They do a lot more research-based designs where we go through, I give them a scenario, something to design and they go through the design process. They brainstorm; they come up with criteria; they develop a design. Sometimes they just write a report on how they would do it. Other times they physically make the design or make a model.

Thus, it was apparent that the academy teachers capitalized on the contextual teaching and learning nature of CTE programs and the career academy model to ensure that students learn content that is meaningful and connected to real-life workplace demands, thereby, increasing the relevancy of the content learned. Further, teachers enabled their students to work in teams, engage in problem-solving contexts, and learn from projectbased activities. These activities replicated the types of interactions and environments they will encounter within the workplace.

A learning curve due to a lack of prior knowledge. Teachers reported working diligently to acquire and learn how to use machines and equipment typically used in local industries, to teach it to their students. All four teachers began their classes with a short lecture to give students the information they needed to complete the tasks assigned for that day or week. Mr. Stein stated, "I always talk to them about the theory, you know, the theory behind a lot of these things". Mr. McGee believed it was necessary to give students "background knowledge" because the career academy was "outside the normal academic realm." Mr. McGee noted that most classes such as math and English built upon prior knowledge from the previous school year: "In my class they're learning about fuse deposition modeling and hot isostatic pressing and they have absolutely no idea what any of that is."

Based on our discussions with the teachers, it was apparent that effective CTE teachers need to have certain teaching dispositions, such as the ability to be adaptable learners and continually develop their skills to keep abreast of the trends and developments within industry. Further, CTE teachers should understand that students likely come into their classrooms with a lack of background knowledge and understanding of the content. Therefore, it is essential to scaffold their instruction based on the individual needs of each student. Overcoming the learning curve, for both the teacher and the students, was articulated as a significant challenge.

Career-related outcomes. Teachers committed to replicating the real-world of work within their classroom settings by deliberately working to provide the necessary equipment used in local industry as well as technical colleges, community colleges, and universities. For example, Mr. Palmer used two CNC stations, a mill, and lathe similar to those used at a local technical college. He explained that students taking his course were awarded hours (dual credit) toward completing the machining program at the college. His long-term goal was to acquire "higher-end equipment" for his advanced students: "If they want to go the manufacturing route, they will actually have a manufacturing line that they can work 
on.” Mr. Wells expressed his desire to update his outdated manufacturing equipment in order to "go with the times" and make sure his students are using the same equipment used in industry to give his students relevant and meaningful experiences.

Mr. McGee recently upgraded from an educational CNC milling machine, used primarily for teaching purposes, to an industry-quality CNC milling machine "that would be used, using the same software, the same interface that are used in industry. So, they're learning on more authentic equipment." He believed such equipment was essential in bridging skills gaps. He described how instructional time in his career academy program assisted students in being more competitive at a local company that makes plastic molds:

You can be a manual machinist and if you've got a high degree of skill, you will always have a job there. However, it takes a long time to build up that level of skill and...you no longer have a lot of machine shops operating manual equipment where you're gonna have opportunities to develop that skill. So you are gonna need to know things like how to set up CNC equipment, how to operate CNC equipment, you're gonna need some programming experience.

The teachers believed their career academy programs used industry-quality equipment to provide their students with the experience needed to develop specific technical skills they will need to overcome a high "barrier to entry" and "skill level to be competent at the entry level” (Mr. McGee).

Furthermore, students were able to gain industry certifications to have a competitive advantage in the workplace that supplements the technical skills they gained. Teachers also encouraged their students to pursue industry certifications to demonstrate what they have learned in class and to be more competitive pursuing jobs and/or enrollment in and completion of two-year or fouryear degree programs. Mr. Palmer spoke extensively about the various benefits of the industry certification:

The biggest improvement is I think the certification exam has really attracted a lot of students because there's a lot they can do with that. Obviously, it can help them with a resume and a college application; it also can help them get a job. We've got several students gonna get internships or paying jobs because of certification, and it attracts a lot of students to our program when you tell their parents that they can become certified in something and they can articulate that certification into a college credit (a free three-hour drafting class).

Therefore, in addition to CTE teachers needing to be adaptive experts, it was apparent that they also needed to work extensively with business and industry partners to understand the current equipment used in real-world work settings. Replicating the real-world work environment within the classroom add to students' experiences. Further, equipping students with value added credentials, such as dual enrollment courses or industry-recognized certifications, in the workforce was critical to providing them with competitive advantages. In sum, the situational uniqueness of CTE programs require teachers to engage, connect, and form relationships with business and industry partners within the local community.

Students: Transforming Ideas into Tangible Products. Contextualized and hands-on learning within the academy. Student comments about using the CNC machines suggested bringing industry-relevant equipment into the classroom was well worth the effort. Students at all four schools, enjoyed programming codes into CNC mills to carve designs into wax blocks. Aaron (Packard HS) used a CNC lathe to take circular tubes of blocks and carve them into chess pieces. He described the CNC lathe station where he did his interview:

It's like a spindle that like grinds away at stuff, and you like program it to do what you need. It's really cool cause [sic] you like get to see like what you do on the computer and then actually see it, like the actual part that you make.

Aaron explained that to build a snowboard, someone could use a CNC lathe to cut the base of the board. The CNC machine, in the lab at Packard HS, was too small to make a snowboard. Nevertheless, it still gave him a "base understanding" of the coding necessary to build a snowboard.

After interviewing the students, it was apparent they perceived that they had benefitted from the contextual teaching and learning of their academy courses. They believed their student experience in the CTE classrooms was meaningful and particularly enjoyed seeing the final products they made as a result. Thus, students seemed to gain a different experience compared to traditional academic courses where content might seem more abstract in nature. Stated differently, students valued and found meaning in coursework when they had tangible outcomes related to their learning. As a result, they were then able to use their new knowledge as scaffolding to inform future projects.

Profession-related student outcomes. Over $80 \%$ of students at three of the four high schools mentioned learning SolidWorks or other CAD/CAM programs in their engineering/engineering technology courses. Most said they earned SolidWorks certification as juniors or seniors, or aspired to do so. Students mentioned CAD programs as something they enjoyed about their class. Student responses highlighted the creative and practical advantages of learning SolidWorks:

I got certified in SolidWorks last year and I actually think the program's kinda neat. You can take an idea in your mind and you can put it on the computer, and then now with our 3D printer in there, we can print that stuff out and we actually, like, hold something that was in our head a few days ago. So, I think that's kinda cool. (Tim, Weston HS)

Students were excited about how they could turn their ideas into tangible 3D items using SolidWorks. 
Dana (Weston HS) said, "I like to engrave things. So, I engrave things for my friends a lot and I like doing SolidWorks 'cause I like starting from nothing and then just seeing how it can become something big." Barry (Weston HS) recalled how Mr. Wells showed him how to look up things other people have designed on the SolidWorks website:

You can print out the instructions on how to build certain things... [S]ay you're building an airplane. It's broken down into different steps... One day you're working on the wings and if you're quick enough you can do, you can almost finish it in one class period, 45 minutes if you're fast.

Barry (Weston HS) explained that SolidWorks was "a little tough" his freshman year, but he could use it on his own without questions by his junior year when he took the certification exam.

Students also discussed the creative utility of learning SolidWorks. Zach (Weston HS) conveys, "I like using the SolidWorks software just because you can pretty much create any part that you want, and if you want to prototype it in the 3D printer.” Dwayne (Weston HS) said:

You can give me a part or tell me to make something like a keyboard or a cell phone. I can create it right on the computer in less than five minutes. It's really easy just using SolidWorks. It's just, that's probably one of the best things I've learned.

David (McArthur HS) wanted to use the architectural drafting skills he has learned to design his own house one day. Jared (Packard HS) and Samuel (Packard HS) mentioned using ArchiCAD software at home to design their own houses. Other Packard HS students mentioned using ArchiCAD and SolidWorks at the aeropneumatics station to show how much air pressure was necessary to push different materials: "[O]n SolidWorks you can test different pressures to see how that stuff would actually work in the real-world before you build it” (Phillip, Packard HS).

Students also noted the practical advantages of learning CAD programs for their job prospects. Dana (Weston HS) described the reaction she received when showing her SolidWorks certificate to people: "People actually looked at [the certificate] and they were like, 'Oh wow, that's really nice' cause some [jobs] require it, actually, so that's been a benefit.” David (Packard HS) did not know about SolidWorks before starting the program. He enrolled in the engineering program "because it seems fun and I get to learn how to self-teach myself how to do lessons and work with my hands.” He noted:

If I want a job that works with hands-on and computer stuff, like SolidWorks... I can learn how to do it for over the years when I get more progressed in it. I can learn more and get used to it.

Jeffrey (McArthur HS) recalled seeing people using CAD programs on an industry tour. He stated:

One guy, he showed us like a drawing of a, not fire engine, but like the pump system they use to pump the water out of a fire truck. And, in the back they showed us like the actual system, the machine, the engine, and they had a bunch of other stuff and like, they showed us the different machines they had over there.

He enjoyed seeing the initial design along with the finished product.

It was apparent that students were learning how to conceptualize a project and think through the steps needed to build their ideas based on their background knowledge of programs (i.e., SolidWorks), and then they were able to transfer their knowledge to novel situations. This process incited excitement and passion for continuing to develop their knowledge and in building other projects. Some students described their abilities to use their knowledge to build things which were functional and of use personally as well as professionally. However, students did not indicate whether what they were learning in their CTE courses were applicable to core academic subject areas. Their teachers also did not mention whether they showed students connections between what they were learning in their CTE courses and how it applies to core academic content.

Student developmental learning challenges. Perhaps most importantly, all students who mentioned SolidWorks, AutoCAD, ArchiCAD, and other CAD programs enjoyed their experiences and believed learning them was beneficial, even those who struggled and/or had difficulty passing certification exams. Noah (Weston HS) aspired to be an electrical engineer and work in a lab making circuit boards and test circuits. He said at first he did not like SolidWorks and was not interested in 3D design: "At first... it didn't seem very fun and that part of the class I didn't really like. But, once I learned [SolidWorks] it got to be really cool and I started to enjoy it." Alissa (Weston HS) did not pass her SolidWorks certification test but appreciated how learning SolidWorks supplemented what she learned in her AP Calculus B and C and Physics Honors courses. She planned to continue taking the test until she passed it.

While it was certainly positive that students enjoyed learning programming software and other technicalrelated content within their CTE courses, it also raised concerns about what CTE teachers did to assist all students in successfully completing exams, as well as what the remediation process was for students having difficulty with passing. We wondered whether students who were repeatedly unsuccessful at passing the certification exams would be disinterested in continuing with the course, and if so, what advice their teachers give them in counseling them regarding possible other career pathways or opportunities.

\section{Discussion}

Much of the discussion surrounding college and career readiness has led to a focus on college readiness to 
the exclusion of career preparedness (Career and Technical Education Technical Assistance Center, 2013). An alternative view of college and career readiness should take into account the reality of the labor market needs, suggesting that a college degree is not necessarily equivalent to being career ready (Barton, 2006; Cappelli, 2008; Symonds et al., 2011). A more nuanced definition of college and career readiness should involve an appropriate set of academic skills in addition to generalizable and specific occupational skills required in broad industry clusters.

Career academy teachers in this study utilized contextual teaching and learning practices to make their content more comprehensible to their students as well as to simulate the real-world work environment within an engineering and engineering technology context. More specifically, they focused on the technological skills (i.e., CAD and CAM software systems) and industryrecognized certifications needed for their students to enter the local manufacturing workforce. While the career academy teachers expressed the difficulties of trying to mimic the real-world work setting within their classrooms, they attempted to replicate the work environment by having students engage in project-based and team-based learning activities to promote problemsolving skills needed in the twenty-first-century workplace (Partnership for $21^{\text {st }}$ Century Skills, 2010). Because of the pedagogical practices employed by academy teachers, students believed their coursework was meaningful as they were highly engaged in working toward constructing tangible products (Newmann et al., 2007; Newmann \& Whelage, 1996; Stipanovic et al., 2012). Therefore, career academy teachers in this study attempted to mimic the manufacturing work environment to ensure students are "right-skilled" and employable upon completion of high school. Nevertheless, students and teachers did not describe in the interviews how their CTE courses connected to core academic content. This problem was reported in prior studies examining students' experiences in career academies (Fletcher \& Cox, 2012). Accordingly, career academy teachers need to demonstrate to students how the content learned in their CTE courses connects to concepts within core academic subjects.

Similar to prior research findings, local employers articulated the challenge of finding qualified potential employees with the knowledge and skills needed to fill vacant positions (Carnevale et al., 2011; Carnevale et al., 2010; Symonds et al., 2011). However, it was apparent that these employers relied solely on the public sector (i.e., secondary and postsecondary educational institutions) to train and prepare their students to enter the local workforce environment. At issue is the sentiment that these local employers did not discuss their commitment (or lack thereof) to provide training for entry-level employees from an internal standpoint. Further, there was no evidence that these local employers were highly engaged in efforts to do so within secondary and postsecondary educational environments. As such, we recommend that business and industry partners play a stronger role in the development of curricula, preparation and training of both students and teachers, and workbased learning experiences (i.e., internships, job shadowing, mentoring) of students within these engineering and engineering technology academies. Stronger work-based learning experiences and schoolemployer partnerships might be a viable strategy to address some of the issues related to the skills-gap reported in recent literature.

Regarding the challenges encountered in mimicking the real-world work environment, teachers discussed the difficulty of staying abreast of current needs in related fields as it pertains to having up-to-date equipment and keeping teachers current with the content knowledge needed to prepare their students for success in manufacturing-related jobs. While this underscores the need for teachers to be adaptive experts (DarlingHammond, Hammerness, Grossman, Rust, \& Shulman, 2005), it is also critical that these school-employer partnerships also include supportive administrators who will facilitate professional development opportunities for teachers to engage with industry representatives as mentors (i.e., "teach the teacher" type sessions). It also seems imperative that schools find funding sources to purchase equipment needed as well as sponsor teachers to participate in industry-related conferences. Hence, there is a strong need for CAPE legislation to help address funding challenges to promote the sustainability of manufacturing-related career academy programs.

Further, while this study focused on student, teacher, and industry experiences, future studies might examine the implementation of career academies across schools and school districts to uncover best practices related to college and career readiness. Studies might compare career academies and their associated student outcomes based on varying levels of fidelity (implementation) and under different contexts and configurations (i.e., comprehensive schools, wall-to-wall academies, and early college high schools) to examine which conditions are related to increased student outcomes. To that end, it would be important to examine career academies supported by agencies such as the National Academy Foundation, which offers technical support for developing, planning, and implementing curricula, professional development of teachers, and adherence to acceptable standards and practices to the career academy model.

\section{Conclusion}

In response to the lack of qualitative research shedding light into the actual experiences of career academy students, this study contributes to our understanding of how career academies provide learning experiences related to preparing students for careers particularly technical skills - within the context of manufacturing-related job areas. Data interpretations 
from our interviews with students, teachers, and industry representatives led to several revelations regarding potential efforts to reduce the skills-gap commonly reported in the research literature.

Note: This research was supported by a grant from the National Science Foundation (NSF \#1104214).

\section{References}

Akerlind, G. (2007). Variation and commonality in phenomenographic research methods. Higher Education Research and Development, 24(4), 321334.

Barton, P. (2006). High school reform and work: Facing labor market realities. Princeton, NJ: Educational Testing Service.

Bradby, D., Malloy, A., Hanna, T., \& Dayton, C. (2007). A profile of the California Partnership Academies 2004-2005. Berkeley, CA: ConnectED and the Career Academy Support Network.

Brown, J. S., Collins, A., \& Duguid, P. (1989). Situated cognition and the culture of learning. Educational Researcher, 18(1), 32-42.

Cappelli, P. (2008, Summer). Schools of dreams: More education is not an economic elixir. Issues in science and technology, 24(4), 60-64.

Career and Technical Education Technical Assistance Center. (2013). Career readiness is more than career and technical education. New York State Education Department: Rexford, NY.

Carnevale, A., Smith, N., \& Melton, M. (2011). STEM: Science, technology, engineering, and mathematics. Washington, DC: Georgetown University, Center on Education and the Workforce.

Carnevale, A. P., Smith, N., \& Strohl, J. (2010). Help wanted: Projections of jobs and education requirements through 2018. Retrieved from Georgetown University, Center on Education and the Workforce website: http:/www9.georgetown.edu/grad/gppi/hpi/cew/pd fs/FullReport.pdf

Castellano, M., Sundell, K., Overman, L. T., \& Aliaga, O. A. (2012). Do career and technical education programs of study improve student achievement? Preliminary analyses from a rigorous longitudinal study. International Journal of Educational Reform, 21, 98-118.

Cohen, M. \& Besharov, D. (2002). The role of career and technical education: Implications for the federal government (Contract No. ED-99-CO-160). Washington, DC: Office of Vocational and Adult Education.

Darling-Hammond, L., Hammerness, K., Grossman, P., Rust, F., \& Shulman, L. (2005). The design of teacher education programs. In L. DarlingHammond, J. Bransford (Eds.), Preparing Teachers for a Changing World: What Teachers
Should Learn and Be Able to Do (pp. 201-231). San Francisco, CA: Jossey-Bass.

Dixon, M., Cotner, B., Wilson, T., \& Borman, K. (2011). Implementing career academies in Florida: A case study approach to understanding successes and obstacles. Career and Technical Education Research, 36(3), 207-227. doi: 10.5328/cter36.3.207

Fletcher, E. (2006). No curriculum left behind: The effects of the No Child Left Behind legislation on career and technical education. Career and Technical Education Research, 31(3), 157-174. doi: 10.5328/CTER31.3.157

Fletcher, E., \& Cox, E. (2012). Exploring the meaning African American students ascribe to their participation in high school career academies and the challenges they experience. The High School Journal, 96(1), 4-19. doi: 10.1353/hsj.2012.0017

Fletcher, E. \& Zirkle, C. (2009). The relationship of high school curriculum tracks to degree attainment and occupational earnings. Career and Technical Education Research, 34(2) 81-102. doi: 10.5328/CTER34.2.81

Florida Career and Professional Education Act. (2007). CAPE - Secondary. Retrieved from http://www.fldoe.org/academics/career-adultedu/cape-secondary

Florida Department of Education. (2006). Technical guide for the 2005-2006 Florida high school graduation rate. Tallahassee, FL: Florida Department of Education. Retrieved from http://www.fldoe.org/eias/eiaspubs/pdf/gradgde.pdf

Florida Department of Education. (2016). Career and professional academies. Retrieved from http://www.fldoe.org/academics/career-adultedu/cape-secondary/resources.stml

Hernández-Gantes, V.M., \& Brendefur, J. (2003). Developing authentic, integrated, standards-based mathematics curriculum: [More than just] an interdisciplinary collaborative approach. Journal of Vocational Education Research, 28(3), 259-284.

Hernández-Gantes, V.M., \& Fletcher, E. (2013). The need for integrated workforce development systems to broaden the participation of underrepresented students in STEM-related fields. In R. Palmer \& L. Wood (Eds.), Community colleges and STEM: Examining underrepresented racial and ethnic (pp. 37-55). New York, NY: Routledge.

Israel, G., Myers, B., Lamm, A., Galindo-Gonzalez, S. (2012). CTE students and science achievement: Does type of coursework and occupational cluster matter? Career and

Technical Education Research, 37(1), 3-20. doi: 10.5328/cter37.1.3

Jenkins, D. (2006, August). Career pathways: Aligning public resources to support individual and regional economic advancement in the knowledge economy. New York: Workforce Strategy Center. 
Kemple, J. (1997). Communities of support for students and teachers: Further findings from $a$ 10-site evaluation. New York, NY: Manpower Demonstration Research Corporation.

Kemple, J., \& Snipes, J. (2000). Career academies: Impacts on students' engagement and performance in high school. New York, NY: Manpower Demonstration Research Corporation.

Kemple, J., \& Willner, C. (2008). Career academies: Long-term impacts on labor market outcomes, educational attainment, and transitions to adulthood. New York, NY: MDRC. Retrieved from: www.mdrc.org/publications/482/full.pdf.

Maxwell, N. \& Rubin, V. (2000). High school career academies: A pathway to educational reform in urban schools? Kalamazoo, MI: W.E. Upjohn Institute for Employment Research.

National Academy Foundation. (2014). Statistics and research: 2013-2014. Retrieved at http://naf.org/statistics-and-research.

National Association of Manufacturers. (2016). Florida per capita income. Retrieved from http://www.deptofnumbers.com/income/florida/\#pe rcap

Newmann, F. M. \& Wehlage, G. G. (1995). Successful school restructuring: A report to the public and educators. Madison, WI: Center on Organization and Restructuring of Schools.

Newmann, F. M., Secada, W. G., \& Wehlage, G. G. (1996). A guide to authentic instruction and assessment: Vision, standards and scoring. Madison, WI: Wisconsin Center for Education Research.

Newmann, F.M., King, P., \& Carmichael, D.L. (2007). Authentic instruction and assessment: Common standards for rigor and relevance for teaching academic subjects. Des Moines, IA: Iowa Department of Education.
Partnership for 21st Century Skills. (2010). Up to the challenge: The role of career and technical education and 21st century skills in college and career readiness. Retrieved from http://www.p21.org/storage/documents/CTE_Oct20 10.pdf

Silverberg, M., Warner, E., Fong, M., \& Goodwin, D. (2004). National assessment of vocational education: Final report to Congress. Washington, DC: US Department of Education.

Stern, D., Dayton, C., \& Raby, M. (2010). Career academies: A proven strategy to prepare high school students for college and careers. Berkeley, CA: University of California Berkeley Career Academy Support Network.

Stipanovic, N., Lewis, M. V., \& Stringfield, S. (2012). Situating programs of study within current and historical career and technical educational reform efforts. International Journal of Educational Reform, 21, 80-97.

Stone, J.R. (2013). Programs of study, college, and career readiness: Career and technical education and making high school matter. Paper presented at the 2013 annual meeting of the American Educational Research Association. Retrieved September 2014, from the AERA Online Paper Repository.

Symonds, W., Schwartz, R., \& Ferguson, R. (2011). Pathways to prosperity: Meeting the challenge of preparing young Americans for the 21st century. Report issued by the Pathways to Prosperity Project, Harvard Graduate School of Education.

Wang, X. (2013). Community colleges and underrepresented racial and ethnic minorities in STEM education: A national picture. In R. Palmer \& J. Wood (Eds.), Community colleges and STEM: Examining underrepresented racial and ethnic minorities (pp. 37-55). New York, NY: Routledge. 